\title{
Sustainable public-private partnerships: Balancing the multi-actor ecosystem and societal requirements
}

C The Author(s) 2018. Published by Higher Education Press. This is an open access article under the CC BY license (http:// creativecommons.org/licenses/by/4.0)

\begin{abstract}
The funding gap of public infrastructure networks (roads, railways, ports, electricity, and energy lines) can be solved partly by introducing private capital for investments, i.e., public-private partnerships (PPP). This paper introduces an integrated model of a PPP project and investigates its implications on PPP policies and strategies regarding appropriate project appraisal and selection. The model has different resolution levels, namely, project level, business ecosystem level, and market and societal levels. The integrated model suggests that investing in merely financially viable projects is insufficient to realize economically and socially sustainable and acceptable projects.
\end{abstract}

Keywords public-private partnerships (PPP), project appraisal and selection, integrated model, socially sustainable

\section{Introduction}

\subsection{Need and forms of PPPs}

Public infrastructure supplies the conditions and services that enable modern society to function properly and create value for its citizens and organizations. The construction, maintenance, and final dismantling after the end of service life of roads, railways, ports, telecommunications net-

Received February 27, 2018; accepted May 25, 2018

Pekka Leviäkangas

Technological Research Centre of Finland Ltd., Finland

Yanbing YE (ه)

School of Civil Engineering and Mechanics, Huazhong University of Science and Technology, Wuhan 430074 China

E-mail: yeyanbing@hust.edu.cn

Oluwole Alfred OLATUNJI

Construction Management Discipline, Curtin University, Australia works, water, and energy supply all require significant amounts of funding. The World Economic Forum (2013) has estimated that the annual global infrastructure funding deficit will increase by at least 1.0 trillion USD, accumulating annually. This funding gap has been acknowledged critically in previous studies, such as in Munnell (1990), which discussed infrastructure budgeting in the United States in the late 1980s.

The funding gap of public infrastructure networks (roads, railways, ports, electricity, and energy lines) can partly be solved by introducing private capital for investments. Public-private partnerships (PPP) and project financing methods have been utilized in industrialized as well as in developing economies. The former suffers more from the challenge of aging infrastructure that calls for more upgrade and replacement investments and the latter from an abject lack of required funds. A PPP is a project asset that is financed by private investors and operated by private operators according to a long-term concession agreed with a public client. A good introduction to PPPs is provided by the World Bank (2014).

This paper draws from several paradigms. One line of thinking that involves PPP is referred to asset restructuring, i.e., outsourcing, commercialization, and privatization of infrastructure. For example, the World Bank, EIB, and OECD and other international institutions have studied the issue extensively (e.g., Heggie and Vickers, 1998 on road sector; Thompson et al., 2001 on railways). In some cases, critical assets have been restructured in lumps, such as the UK's railway infrastructure as a part of larger asset restructuring package (Nash, 1993; Welsby and Nichols, 1999). In other cases, assets have been restructured on a project-by-project basis. The latter is closest to PPP and project finance (Välilä, 2005; Blanc-Brude et al., 2006; Leviäkangas, 2007) where the private investors or their affiliates assume financing, building, and operating the infrastructure. The other paradigm that is related to PPPs is new institutional economics (e.g., Coase, 1984; Menard and Shirley, 2005) which studies organizational arrange- 
ments within the framework in which asset restructurings can be carried out.

The terminology throughout this paper is consistent regarding the terms "financing" and "funding." The PPPs are not funded by governments but financed by the private sector investors. The funding gap is filled by private finance. Hence, financing entails interest and return, whereas funding is merely something that is handed out free of charge. However, the terms are interchangeable in everyday language in practice.

Each PPP arrangement provides stakeholders with a deeper consideration of the different fragments in traditional procurement processes. It also offers a strong integration of project procurement structures such that public institutions can share and/or transfer risks to the private sector, involving the private sector as equal partners but with a clear advantage in triggering innovation and cocreation.

Through a PPP arrangement, public institutions also retain the absolute power to control ownership of assets and optimize quality of service delivery whether during or after the concession period. Liu et al. (2015) identified specific critical success factors around these. Unlike in tradition procurement processes, the authors found that PPP projects require some comprehensive objective preproject assessment such that investors can manage risks, optimize value for money, and plan project feasibility effectively right from the initial planning stage. They also found that PPP projects require some sound procurement practices, and projects must operate under an appropriate governance structure, with standardized and transparent bidding and a thorough negotiation process.

Some general guidelines on how to implement PPPs are available. For instance, the Asian Development Bank (undated), the United Nations (United Nations, 2008; UNESCAP, 2011), and the World Bank (2014) have issued guidelines. However, these guidelines are generic and do not necessarily work on individual project level. Technical, simple-to-use, and hands-on tools are still needed.

A set of standards is being prepared by the United Nations Economic Committee for Europe. The standards emphasize sustainable development goals of the United Nations (UNECE, 2016). For example, the draft standards for railway PPPs focus on political acceptability, processing of capital investment programs, and ensuring the viability of processes (Beckitt, 2016).

\subsection{PPP experience}

In Australia, infrastructure is one of the largest national asset classes. It accounts for just under a quarter of Australia's GDP annually. A key success factor is that government provides only a portion of the nation's infrastructure assets. All levels of government in Australia rely on partnerships with the private sector to procure critical infrastructure projects. Thus, the government can focus on valuable governance by providing strategic leadership that enables robust investment climate and by triggering faith and growth in every sector of the economy. A single most significant attribute of PPP is that it often succeeds with minimal or no initial cost to taxpayers. In Australia, instances have been observed where government has incentivized private participation even further by providing enablers such as assurances regarding cost recovery (e.g., user fees) and subsidies (Regan et al., 2011). Swan (2008) cited a deposit guarantee system provided by the Australian government during economic downturns.

PPPs ensure critical assets are procured effectively, timely, within budget, and at a reduced cost of procurement (Regan, 2008). In addition, another clear advantage of PPPs is that assets are run efficiently toward a maximum viability level for a substantial period. Empirical evidence elicited by Regan et al. (2011) regarding procurement outcomes of infrastructure projects between 1999 and 2006 suggests $79 \%$ of PPP projects in Australia were finished within budget, $82 \%$ on time, and to a user benefit satisfaction of $74 \%$ compared with $25 \%$ completions on budget, $34 \%$ completions on schedule, and $27 \%$ user benefit satisfaction in projects procured through traditional processes.

In China, infrastructure remains in short supply. The infrastructure demand is large, but the total amount of funds used by the governments is insufficient (Ke et al., 2011). PPPs can relieve the fiscal pressure and provide better financing channels for local government infrastructure construction. The second phase of Wuhan's East Lake G Greenway is a typical PPP project. The project's total investment is 545 million dollars from three agencies, and the PPP model applied is finance-build-operate-transfer (see next section for the definition of PPP models). The agencies (social capital investment units) and the project company are responsible for the project investment and financing, construction, operation, and maintenance. After a concession period of 11 years, the road asset will be transferred to the government for free.

PPP projects are already mainstream procurements in China. China PPP Center (2017) disclosed that the total number of PPP projects in China was 14220, with a total investment of 2.77 trillion CNY by September 2017. On the other hand, some local governments in China still face financing constraints. The government also takes more risks owing to the mismatch between the power and responsibility of the private sector and the government. For example, the project is in the name of PPP but is implemented as build-transfer (BT) mode, causing the government ultimately to take full risk of the whole operation and maintenance period (Xu et al., 2014). Many non-standard practices and challenges have been observed in the implementation of PPPs, such as lack of collabora- 
tion and performance assessment (Qi et al., 2009). All these problems have resulted in several extrusion effects, influencing the progress of PPPs in China.

Some evidence points out that PPPs have been quite unsuccessful in countries with lesser institutional maturity and stability (Witz et al., 2015). In countries where PPPs already have a long tradition, the view to PPPs is sometimes critical. For example, a UK House of Commons Treasury Committee report (2011) states: "Significantly higher cost of finance can be offset sufficiently because the evidence of savings and benefits in other areas of $\mathrm{PFI}^{1)}$ [i.e., PPP] projects cannot be seen clearly." Cruz and Marques (2011) published their assessment on Portuguese PPP projects that caused the public economy facing a massive financial burden.

On the other hand, PPPs also have positive effects on infrastructure delivery. References or empirical evidence are not needed to realize that the deployment of private capital can contribute to development of infrastructure, especially in cases where the public budgets are severely constrained. In Finland, PPP projects are considered successful (Finnish Transport Agency, 2013; Leviäkangas et al., 2013). The Arlandabanan project, the train link between the airport and center of Stockholm, was conducted and operated smoothly (Nilsson et al., 2008) despite changes in the ownership and governing structures. Before the term PPP came into existence, many Norwegian toll roads were built and have been operating for decades (Leviäkangas, 1996; Odeck, 2008). Although the Norwegian toll roads should perhaps not be simply regarded as PPPs because the local authorities are often the sole shareholders of the toll companies, they are nonetheless public investments utilizing private capital, with major banks being the debt investors.

\subsection{Motivation and aims of this study}

The evidences and experiences are to some extent contradictory, and despite a clear "market push" for PPPs, the need for balanced, transparent, and objective approaches is apparent. The need is weighed by the fact that in countries with institutional maturity and good governance, the experiences have been generally more positive (e.g., Finland and Australia) because the logical assumption is PPPs have been treated more objectively and transparently in these cases.

Whatever the national or institutional context is, replacing public funding with private capital finance does not change the project's socio-economic viability (although it changes the financial viability). However, bringing in the private investors requires understanding how the costs and benefits must be distributed between ecosystem actors. Otherwise, justifying the project to all stakeholders may be difficult. Therefore, the socio- economic and financial "statement" of the project must be extensive enough for the sake of the project to become acceptable for the public, investors, contractors, administrators, and for different market and societal stakeholders (Leviäkangas et al., 2016a). Models that can capture the rationale of the value co-creation in a PPP project ecosystem are needed to de-politicize and neutralize ideological loadings which are often present in PPP projects.

The aim is to provide an integrated model of a PPP project and investigate the model's implications on PPP policies and strategies regarding appropriate project appraisal and selection. The model integration is done step-by-step on different resolution levels of analysis: 1) PPP project level, 2) PPP business ecosystem level, and 3) market and societal levels. The integrated model is valid provided the partial models used for its construct are valid, and logical congruence exists between different models.

The proposed model is novel, and the structure proposed needs empirical validation.

\section{Key concepts}

\subsection{PPPs}

PPP has no universally accepted standard or definition. Several arrangements between the public and private sector fall under the umbrella of PPP. Typically, PPPs are long-term contracts between a private party or consortium and a public (local or national) body to supply a public asset or service through utilization of private funds. In many cases, both the physical asset and the service are bundled. In typical PPPs, the private party or parties bear considerable share in risks and management responsibility (World Bank, 2014).

PPPs must be distinguished from privatization. Privatization means transferring public assets to private investors/ owners. If the legal status of the public asset is changed into a limited liability company or some other form of vehicle, in which the owners' liabilities are defined in a different manner and the operating logic of becomes more commercially oriented, the correct term is "corporatization." Corporatization is not synonymous to privatization if the asset is still held by the government (e.g., a state-owned company).

PPPs should not be privatization or transformations (corporatizations). For projects that private investors can invest in, the private investment is used to create the opportunity to gain a return on profits. In these projects, the cash flow logic can vary substantially. Moreover, the cooperation between the public and the private sector can range from technology procurement to joint shareholding in assets. PPPs can fill the space between traditionally

1) Private finance initiative: A way of creating PPPs by funding public infrastructure projects with private capital; a term used especially in the UK. 
procured public projects and full privatization (Grimsey and Lewis, 2005).

One of the most commonly used structures for PPPs is a project company. A project company is established to finance, build, and operate the asset. Private investors build the company by investing necessary equity and debt capital so that the project company has the resources to run. Construction and operation can be separated into two different project companies. Project companies are often called special-purpose vehicles (SPV), which describe the dedicated nature of the company, that is, it is built for one purpose only. However, SPVs are generic entities because they describe any type of arrangement (including project companies) with a single purpose. For example, an SPV can be created to avoid taxes or to stock risky finance.

PPPs do not simply emerge as project companies because of eager investors; they must be procured, at least when the context is publicly owned infrastructure. Infrastructure procurement by PPP has its nuances. How the peculiarity of each nuance is understood is important to how project success is driven. In a build, operate, and transfer (BOT) arrangement (Tiong and Yeo, 1993; Leviäkangas, 2007), the public sector provides land, designs, and performance specifications, whereas private investors build the assets, operate, and transfer operation back to the public after a stipulated period (mostly after 25 years). BOT operators do not own the assets because such projects are financed by government institutions. Build, own, operate, and transfer (BOOT) requires private investors to build, own, operate, and transfer assets back to the public after a stipulated period. A variant of this is ROOT, in which case "rehabilitate" replaces "build," and the arrangement works only for an existing facility. BT arrangement means private investors neither own nor operate assets, e.g., classified security assets. Build, own, and operate (BOO) arrangement means private investors can own and operate assets in perpetuity. Similar to ROOT, a variant of $\mathrm{BOO}$ is $\mathrm{ROO}$ in which cause private investors can rehabilitate, own, and operate assets in perpetuity. In addition, the private sector provides design and finance services to these various forms of PPP arrangements. For example, design and finance could be added to BOT to form DFBOT, to BOOT/ROOT to form DFBOOT/ DFROOT, or to BT and BOO to form DFBT and DFBOO, respectively.

\subsection{Business ecosystems}

Businesses are gradually offering specific products or services in a wider network composed of related businesses. A business ecosystem is a network of interrelated companies (such as pincers and distributors) that interact with each other, mainly to complement or provide value claims or benefits for customers in their products or services (Financial Times, 2017).
The principles of business ecosystems assume that companies seek proactive responses to increased competitive pressure through a mutually beneficial relationship between the customer and the supplier (Iansiti and Levien, $2004 a ; 2004 b)$. The flow of knowledge and the sharing of value creation bring actors to the business ecosystem. PPPs may be viewed as business ecosystems. In a PPP context, the business ecosystem must include regulators, investors, partners up- and downstream the supply chain, and stakeholders subjected to PPP projects' effects (including externalities) (Leviäkangas et al., 2016). A description of the ecosystem for an infrastructure asset is shown in Fig. 1. The asset may be a network, a part of the network, or a node.

The common basis of PPP project ecosystem is participants' common goals, and participants need to understand their role in ecosystem. The ecosystem of a project company plays a role in the project life cycle, including execution and operation. This is not very different from the ideology of the common platform or the common market, where the participants in the ecosystem can work together to achieve common goals. The ecosystems of infrastructure PPPs involve many different markets and stakeholders (Leviäkangas et al., 2015).

\subsection{Infrastructure market layers}

Infrastructure serves several market layers, and multiple types of organizations are involved as market actors (Leviäkangas et al., 2011; Leviäkangas et al., 2015). For instance, electricity networks can have multiple electricity producers, they have multiple clients in the corporate and consumer segments, and they may compete with other networks for the transfer of electricity. The networks may be public, semi-public (e.g., municipality- or city-owned companies), or private firms. Entities with different legal forms may have different business logic, and they may be treated differently in terms of regulation, taxation, and so on. The market layer idea is essential in the modeling process toward the integrated model and will be shown in Section 3 (Table 2).

Infrastructure projects have far-reaching and wideranging economic, social, and environmental effects. These effects, when not priced by the markets, are considered as externalities. Infrastructure PPPs result in these externalities that significantly affect the projects' acceptability and profitability. Hence, the appraisal of the projects cannot be limited to investor logic but must be a holistic appraisal of the effects covering all necessary stakeholders. Stakeholders could include non-human entities, such as flora and fauna. The more extensive the project context is, namely, size, volume, foreseeable effects, and so on, the more holistic the appraisal framework must be, and the greater the weight which must be given to externalities. 


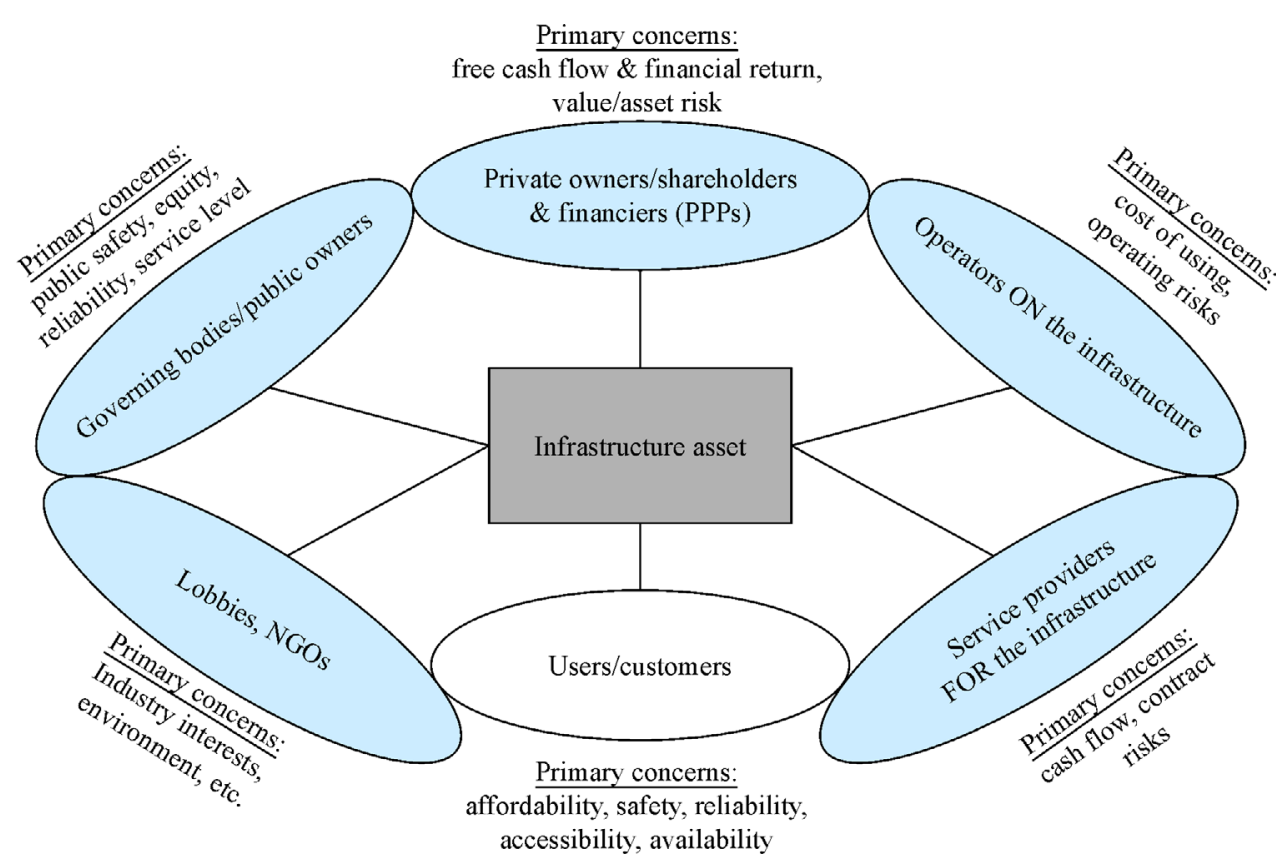

Fig. 1 Infrastructure asset ecosystem

\section{PPP model construct}

\subsection{PPP as a project and as an ecosystem}

Figure 2 illustrates the model of a generic PPP project. Investors invest either debt or equity in the project company. The project company orders the asset construction works from contractors and suppliers. The financing from investors must be able to support this upfront investment. The public-sector client, the State (or equally so a local government), plays a role through collecting taxes and possibly assigning subventions to the project company. The users use the asset and might pay for that use; the users also enjoy the benefits from the asset that serves their needs. The exact nature of subventions and user payments depends on the formulation and content of the concession contract.

The project model cash flows can be allocated in an ecosystem matrix that can be applied to virtually any type of infrastructure PPP. The business ecosystem model

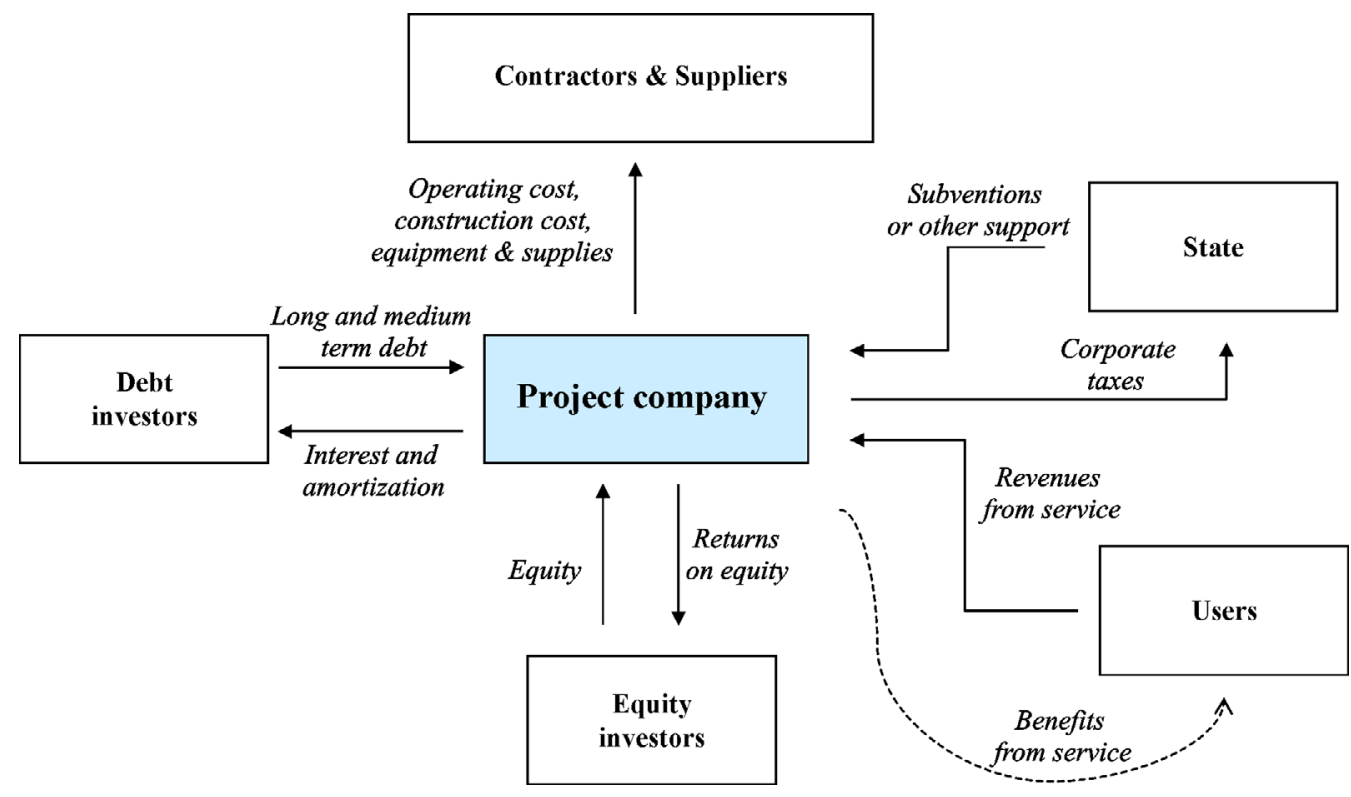

Fig. 2 Single-project company model 
Table 1 PPP project ecosystem economy matrix

\begin{tabular}{|c|c|c|c|c|c|c|}
\hline \multicolumn{3}{|c|}{ PPP project ecosystem cash and economic flow statement } & \multirow[b]{2}{*}{ Users } & \multirow[b]{2}{*}{ State } & \multirow[b]{2}{*}{ Contractors and suppliers } & \multirow[b]{2}{*}{ Notes and explanations } \\
\hline $\begin{array}{l}\text { Debt } \\
\text { investors }\end{array}$ & Equity investors & $\begin{array}{l}\text { Project } \\
\text { company }\end{array}$ & & & & \\
\hline \multirow{6}{*}{$\begin{array}{l}\text { Debt investment } \\
\text { and return }\end{array}$} & Equity investment & Equity capital & & & \multirow{6}{*}{$\begin{array}{l}\text { Revenues from } \\
\text { construction and } \\
\text { operating services }\end{array}$} & $\begin{array}{l}\text { Equity investors invest in the } \\
\text { project company }\end{array}$ \\
\hline & & $\begin{array}{l}\text { Debt capital and } \\
\text { interest on debt }\end{array}$ & & & & $\begin{array}{l}\text { Debt investors invest in the } \\
\text { project company; the company } \\
\text { pays the interest on debt }\end{array}$ \\
\hline & & $\begin{array}{l}\text { Construction and } \\
\text { operating cost }\end{array}$ & & & & $\begin{array}{l}\text { Project company constructs } \\
\text { the facility and pays the con- } \\
\text { tractors and suppliers }\end{array}$ \\
\hline & & $\begin{array}{l}\text { Revenues from users } \\
\text { and subsidies from the } \\
\text { state }\end{array}$ & $\begin{array}{l}\text { Payments for } \\
\text { services }\end{array}$ & $\begin{array}{c}\text { Subsidies to the } \\
\text { project }\end{array}$ & & $\begin{array}{l}\text { Project company receives } \\
\text { revenues from the state or } \\
\text { from the users }\end{array}$ \\
\hline & & Taxes paid & & Taxes collected & & $\begin{array}{c}\text { Corporate taxes after } \\
\text { expenses, depreciation, and } \\
\text { interest }\end{array}$ \\
\hline & & & \multicolumn{2}{|c|}{$\begin{array}{l}\text { Benefits received by users plus the } \\
\text { external benefits (and costs) }\end{array}$} & & $\begin{array}{l}\text { State takes benefits of users } \\
\text { and third parties into account, } \\
\text { that is, the external benefits } \\
\text { and external costs }\end{array}$ \\
\hline$\sum$ & $\sum$ & $\sum$ & $\sum$ & $\sum$ & $\sum$ & \\
\hline
\end{tabular}

Note: The surplus cash flow available for share and debt holders, paid by the project company; payments to suppliers and contractors; benefits and costs for users and public-sector client (society).

Market value of the project equals free cash flow available for investors of debt and equity.

Table 2 Layered markets and market contexts of an infrastructure PPP

\begin{tabular}{lc}
\hline Market "layers" & Functions \\
\hline $\begin{array}{l}\text { End-user market } \\
\text { (commodity market) }\end{array}$ & Consumption and use of produce (goods and services) \\
$\begin{array}{l}\text { Infrastructure user } \\
\text { market }\end{array}$ & $\begin{array}{l}\text { Use of infrastructure; services ON the infrastructure } \\
\text { Infrastructure services and infrastructure supply }\end{array}$ \\
$\begin{array}{l}\text { Capital market } \\
\begin{array}{l}\text { Regulatory and } \\
\text { administrative system; the society }\end{array}\end{array}$ \\
\hline
\end{tabular}

simply distinguishes the actors or stakeholders and allocates the financial or economic "transactions" between actors (for each "debit," a "credit" exists). The matrix shows that summing up each stakeholder's net financial/ economic position is straightforward, column by column, provided that the valuation and operationalization of the items are successful.

The non-cash benefits and external costs generated by the project are monetized using standard cost-benefit analysis (CBA). However, the challenge is that a standard does not exist.

What is typical for many PPP projects is the direct collection of revenues from the users of the provided services, often supplemented by subsidies of some nature from the public sector.

\subsection{Market model and integrated model}

The market context for infrastructure PPPs is modeled as "layers" that approximate the value chain from institutional planning of the infrastructure to execution and operation of the project asset (Leviäkangas et al., 2015).

- Regulations and standards guide and limit any infrastructure design and how the envisaged project is (or should be) processed when progressing toward implementation and realization.

- The capital market offers the financing resources for the infrastructure. If the design is processed without major problems, necessary decisions and commitments are made on political and administrative levels, and the project enterprise can raise enough capital from the investors, the 
process takes steps to engineering design, procurement, and actual commencement of the project.

- Once completed, the project asset starts to serve consumer, industries, and service providers that operate the infrastructure or provide services on the infrastructure, such as transport and logistics operators.

The market, project, and ecosystem models are integrated into a single framework to form an integrated model. This model combines conceptual structure and model analysis and description. It distinguishes the transactional processes between the ecosystem actors and the value-adding processes of functions or market layers.

In the integrated model, the upper level includes flows can be regarded as market transactions. It is capital supply and transaction between contractors and suppliers, as well as SPV. However, the lower level flows include the valueadding dynamics between different market layers, where the infrastructure investments play a key role. The infrastructure provides an investment object for the capital market and the business context for contractors, suppliers, and service providers that use the infrastructure as their platform. For the entire system to be value adding and efficient in a wider financial, economic, and social sense, the dynamics between the layers must be understood. For example, the state must simultaneously consider multiple issues, such as the need for subventions and how the key elements of socio-economic benefits and externalities are distributed among community, economy, and society. (Table 3)

The model's resolution can be tailored according to the needs at hand. The ecosystem financial and economic statement (Leviäkangas et al., 2016a) can be "fit in" to this integrated model to analyze and assess PPPs. Contractor and supplier actors in the infrastructure supply and services layer can be divided into as many sub-actors and-layers as necessary or feasible. The resolution needs depend on the situation, project maturity, and information needs of the decision maker/assessor.

\section{Discussion}

PPPs must be understood in a wider sense beyond investment objects. The success of any major investment project is not only dictated by the "cash flow" economy but also by a more holistic view of the economy. Saying that systemic project appraisal is overwhelmingly difficult is not correct because it is not. The challenge is to understand the value creation system of infrastructure projects, including PPP projects, and to make the effort to transparently perform the ecosystem's cost and benefit calculus that covers the relevant stakeholders.

The integrated model suggests that investing in merely financially viable projects (from the viewpoint of the investors) is not sufficient to realize economically and socially sustainable and acceptable projects. The challenge is thrown at both sides: The investors and the capital market on one hand and the governments and public-sector officials on the other. If either side does not capture the full picture, a fruitful consensus cannot be built for a truly sustainable PPP project. All benefits and costs, including the non-monetary ones, should be spread over the table to form a picture of the total effects for each stakeholder. Only then are the negotiations and assessments done on a fair and transparent basis. The proposed model is a tool for information exchange for such types of negotiations. However, the model also needs to be validated and tested empirically to confirm that it works in the chosen context. This limitation is dependent on the success of the PPP project and the skills of experts who will have to consider the project (e.g., public administrators, private financiers, or political decision-makers).

The more practical challenge comes with the fact that the full picture requires some quantification (or at least very good qualitative assessment) of externalities, such as effects on environment, quality of life within the vicinity of the project, and so on, which may be difficult to assess. In the current framework hierarchy of human needs, these effects are receiving an increased emphasis and attention. Investors may have to step away from the role of an "accountant" and step into the shoes of an "environmentalist" and "social worker," and the same widening of perspective applies to authorities and decision makers responsible for infrastructure development projects. CBA must also be improved to include elements that facilitate more holistic project appraisal.

Table 3 Integrated PPP model

\begin{tabular}{|c|c|c|c|c|c|c|c|}
\hline \multicolumn{8}{|c|}{ Ecosystem actors } \\
\hline $\begin{array}{l}\text { "Fiscal" } \\
\text { government }\end{array}$ & $\begin{array}{l}\text { Debt inves- } \\
\text { tors }\end{array}$ & $\begin{array}{l}\text { Equity } \\
\text { investors }\end{array}$ & $\begin{array}{l}\text { Project } \\
\text { company }\end{array}$ & $\begin{array}{l}\text { Contractors } \\
\text { and } \\
\text { suppliers }\end{array}$ & $\begin{array}{l}\text { Operators } \\
\text { and } \\
\text { producers }\end{array}$ & $\begin{array}{l}\text { Private } \\
\text { users }\end{array}$ & $\begin{array}{c}\text { Consumers of } \\
\text { produce, } \\
\text { industries }\end{array}$ \\
\hline \multicolumn{8}{|c|}{$<==$ Transactional flows between actors $==>$} \\
\hline \multicolumn{8}{|c|}{ Value-adding flow in the economy $==>$} \\
\hline \multirow[t]{2}{*}{ Regulatory system, policy } & \multicolumn{2}{|c|}{ Capital market } & $\begin{array}{l}\text { PPP } \\
\text { market }\end{array}$ & $\begin{array}{c}\text { Infrastructure } \\
\text { supply and services }\end{array}$ & \multicolumn{2}{|c|}{ Infrastructure users } & $\begin{array}{l}\text { End-user } \\
\text { market }\end{array}$ \\
\hline & & & Market la & d functions1 & & & \\
\hline
\end{tabular}



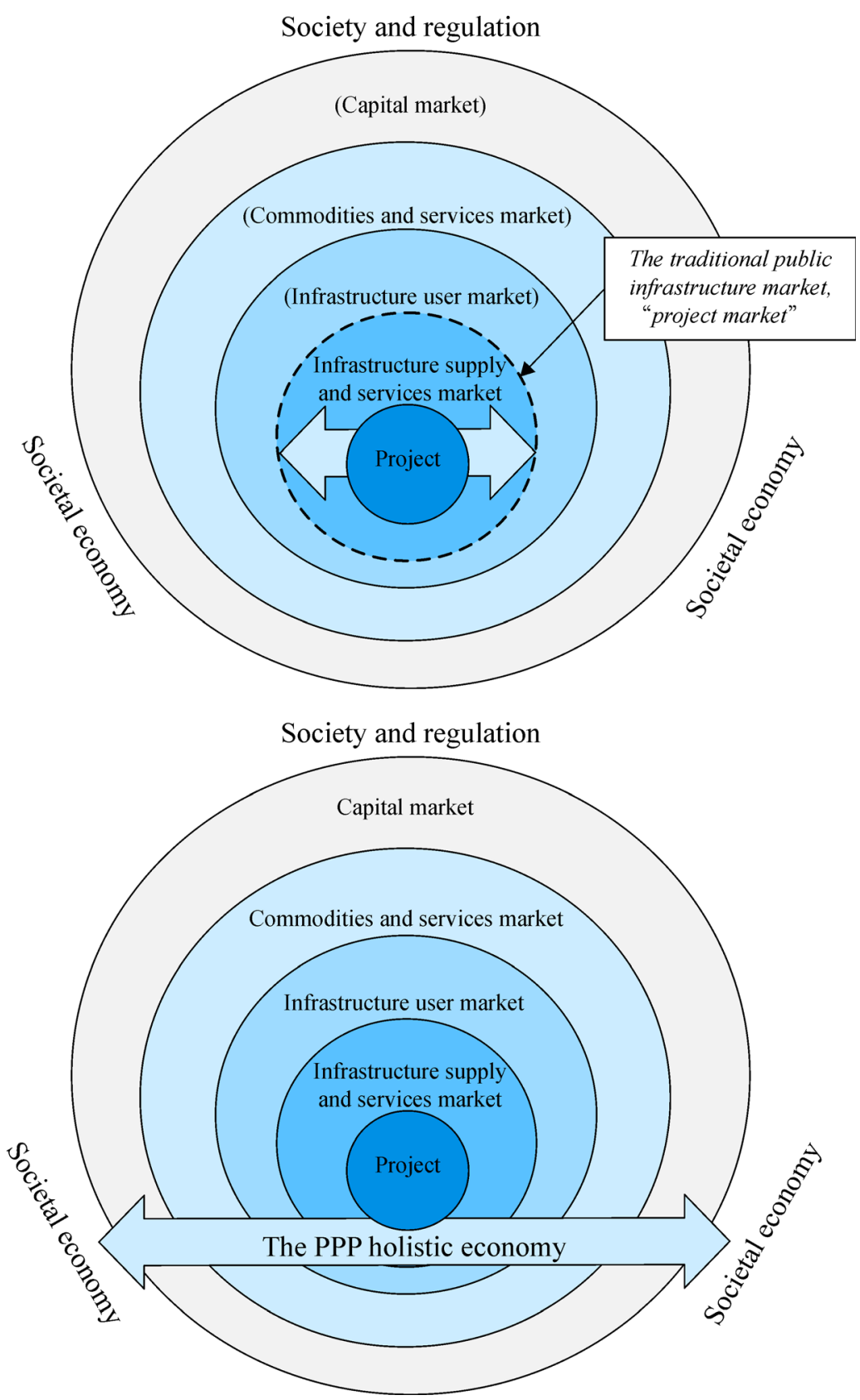

Fig. 3 Changing the perspective: From project business to systemic value creation

\section{Conclusions}

In conclusion, both empirical and theoretical evidence show that PPPs can be well designed or poorly designed. The literature and empirical experience from Australia, China, and Finland attest that in most cases, PPPs succeed to deliver timely, in-budget, and good-quality outcomes. However, the theoretical model, which we call the integrated model, shows how the entire business ecosystem must be served alongside wider socio-economic ecosystem, which we call the infrastructure asset ecosystem (Fig. 1). Only a holistic stakeholder perspective involving technical, social, and financial aspects will ensure that PPPs are truly "good" projects in the eyes of the public, for the investors, and for the administrating bodies responsible for the public good. The model we propose can capture these viewpoints, can be tailored to different kinds of infrastructure PPPs, and is context-independent.

\section{References}

Asian Development Bank (2016). Public-Private Partnership Handbook. 
http://www.apec.org.au/docs/ADB\%20Public\%20Private\%20Partnership\%20Handbook.pdf, 2016-6-3

Beckitt J (2016). Proposed draft, UNECE PPP standard for rail programmes. United Nations Economic Commission for Europe, Team of Specialists on Public-Private Partnerships (TOS PPP). Interim draft v3. Restricted

Blanc-Brude F, Goldsmith H, Välilä T (2006). Ex ante construction costs in the european road sector: A comparison of public-private partnerships and traditional public procurement. EIB Economic and Financial Report 2006/1

China Public Private Partnerships Center (2017). National PPP comprehensive information platform project management library. http://www.cpppc.org:8082/efmisweb/ppp/projectLibrary/toPPPMap.do, 2017-10-15

Coase R H (1984). The new institutional economics. Journal of Institutional and Theoretical Economics, 140(1): 229-231

Cruz C, Marques R C (2011). Revisiting the portuguese experience with public-private partnerships. African Journal of Business Management, 5(11): 4023-4032

Financial Times (2017). Definition of business ecosystems. http:// lexicon.ft.com/Term?term $=$ business-ecosystem\&mhq5j $=\mathrm{e} 2$

Finnish Transport Agency (2013). Elinkaarimallin jälkiarviointi [Ex post analysis of PPP]. www.liikennevirasto.fi

Grimsey D, Lewis M K (2005). Are public private partnerships value for money? Evaluating alternative approaches and comparing academic and practitioner views. Accounting Forum, 29(4): 345-378

Heggie I G, Vickers P (1998). Commercial Management and Financing of Roads. Washington, D.C.: World Bank

House of Commons Treasury Committee (2011). Private Finance Initiative. Seventeenth Report of Session 2010-2012. The Stationary Office Limited, 08/2011

Iansiti M, Levien R (2004a). Strategy as ecology. Harvard Business Review, 82(3): 68-78, 126

Iansiti M, Levien R (2004b). The Keystone Advantage: What the New Dynamics of Business Ecosystems Mean for Strategy, Innovation and Sustainability. Boston: Harvard Business School Press

Ke Y J, Wang S Q, Chan P C, Cheung M E (2011). Understanding the risks in China's PPP projects: Ranking of their probability and consequence. Engineering, Construction and Architectural Management, 18(5): 0969-9988

Leviäkangas P (1996). Road toll Financing in Norway. Finnish Road Administration internal publications 37/1996 (in Swedish)

Leviäkangas P (2007). Private Finance of Transport Infrastructure Projects-Value and Risk Analysis of a Finnish Shadow Toll Road Project. Dissertation for the Doctoral Degree. Espoo: VTT Publications

Leviäkangas P, Kinnunen T, Aapaoja A (2016). Infrastructure PPP project ecosystem-financial and economic positioning of stakeholders. European Journal of Finance, 22(3): 221-236

Leviäkangas P, Nokkala M, Rönty J, Talvitie A, Pakkala P, Haapasalo H, Herrala M, Finnilä K (2011). Ownership and Governance of Finnish Infrastructure Networks. Espoo: VTT Publications

Leviäkangas P, Ojala L, Töyli J (2016a). Understanding infrastructure PPPs - the project, the ecosystem, the markets and the societal economy. Utilities Policy, 42: 10-19

Leviäkangas P, Nokkala M, Talvitie A (2015). A slice or the whole cake?
Network ownership, governance and public-private partnerships in Finland. Research in Transportation Economics, 49: 2-13

Leviäkangas P, Wigan M, Haapasalo H (2013). Financial anatomy of E4 Helsinki-Lahti shadow toll PPP-project. Built Environment Project and Asset Management, 3(2)

Liu J, Love P E D, Smith J, Regan M, Davis P R (2015). Life cycle critical success factors for public-private partnership infrastructure projects. Journal of Management Engineering, 31(5): 04014073

Menard C, Shirley M (2005). Handbook of New Institutional Economics. Cheltenham: Edwar Elgar

Munnell A (1992). Infrastructure investment and economic growth. Journal of Economic Perspectives, 6(4): 189-198

Nash C (1993). Rail privatisation in Britain. Journal of Transport Economics and Policy, 27(3): 317-322

Nilsson J E, Hultkrantz L, Karlstrom U (2008). The Arlanda airport rail link: Lessons learned from a Swedish construction project. Review of Network Economics, 7(1): 77-94

Odeck J (2008). How efficient and productive are road toll companies? Evidence from Norway. Transport Policy, 15(4): 232-241

OECD (2007). Transport infrastructure charges and capacity choiceSelf-financing road maintenance and construction. European Conference of Ministers of Transport, Round Table 135

Qi X, Ke Y, Wang S Q (2009). Analysis of critical risk factors causing the failures of China's PPP projects. China Soft Science, 5: 107-113 (in Chinese)

Regan M, Smith J, Love P E D (2011). Impact of the capital market collapse on public-private partnership infrastructure projects. Journal of Construction Engineering and Management, 137(1): 6-16

Regan M E (2008). What impact will current market conditions have on public private partnerships? Bond University and the Infrastructure Association of Queensland, Australia

Swan W (2008). Budget speech 2008-09. The Parliament, Commonwealth of A-ustralia, Canberra. http://www.budget.gov.au/2008-09/ content/speech/download/speech.pdf, 2018-1-4

Thompson L S, Budin K J, Estache A (2001). Private investment in railways: Experience from South and North America, Africa and New Zealand. European Transport Conference

Tiong R, Yeo K T (1993). Project financing as a competitive strategy in winning overseas jobs. International Journal of Project Management, 11(2): $79-86$

UNECE (2016). UNECE launches a new programme to develop international PPP standards. http://www.unece.org/index.php?id= 36228

UNESCAP (2011). A guidebook on public-private partnership in infrastructure. United Nations Economic and Social Commission for Asia and The Pacific, Bangkok

United Nations (2008). Guidebook on Promoting Good Governance in Public-Private Partnerships. United Nations Report

Välilä T (2005). How expensive are cost savings? On the economics of public-private partnerships. EIB Papers, 10(1)

Welsby J, Nichols A (1999). The privatisation of Britain's railways: An inside view. Journal of Transport Economics and Policy, 33(1): 5576

Witz P, Leviäkangas P, Łukasiewicz A, Szekeres K (2015). Implementation of transport infrastructure PPPs in the Czech Republic, Finland, Poland and Slovakia - A comparative analysis on national 
contexts. International Journal of Management and Network Economics, 3(3): 220

World Bank, Asian Development Bank, Inter-American Development Bank (2014). Public-private partnerships: Reference guide, version 2.0. World Bank, Washington, D.C.; Asian Development Bank, Mandaluyong City, Philippines; Inter-American Development Bank,
Washington, D.C. https://openknowledge.worldbank.org/handle/ 10986/20118

Xu Y L, Yeung F Y, Jiang S H (2014). Determining appropriate government guarantees for concession contract: lessons learned from 10 PPP projects in China. International Journal of Strategic Property Management, 18(4): 356-367 